\title{
Early Skin Rash and Cetuximab-Based Therapy of Advanced Biliary Tract Cancer
}

\author{
Viroj Wiwanitkit $^{1,2,3,4,5,6}$
}

Received: 8 May 2017 / Accepted: 28 May 2018 / Published online: 1 June 2018

(C) Arányi Lajos Foundation 2018

Dear Editor, the recent report on "Early Skin Rash and Cetuximab-Based Therapy of Advanced Biliary Tract Cancer" is very interesting [1]. Rubovszky et al. suggested that "early skin rash can be used as a biomarker to select patients who would benefit from the treatment with cetuximab plus chemotherapy [1]." In fact, skin rash is a paraneoplastic sign in advance biliary tract cancer [2]. The sign might be a possible biomarker but there are some concerns. First, the skin rash can be due to other causes (such as irritant contact) and this cannot be ruled out in the present report by Rubovszky et al. Dermatological investigation is required for diagnosis of the skin rash. Second, the cause of advanced biliary tract cancer can be due to the infectious etiology. In my setting in Southeast Asia, liver fluke is the main infection that leads to advanced biliary tract cancer. Of interest, the liver fluke infestation can also induce the skin rash [3].

\section{Compliance with ethical standards}

Conflict of interest None.

\section{References}

1. Rubovszky G, Budai B, Ganofszky E, Horváth Z, Juhos É, Madaras B, Nagy T, Szabó E, Pintér T, Tóth E, Nagy P, Láng I, Hitre E (2017 Apr 29) Predictive Value of Early Skin Rash in Cetuximab-Based Therapy of Advanced Biliary Tract Cancer. Pathol Oncol Res. https://doi.org/10.1007/s12253-017-0238-y [Epub ahead of print]

2. Opneja A, Mahajan S, Kapoor S, Marur S, Yang SH, Manno R (2015) Unusual Paraneoplastic Presentation of Cholangiocarcinoma. Case Rep Med 2015:806835

3. MacLean JD, Graeme-Cook FM (2002 Apr 18) Case records of the Massachusetts General Hospital. Weekly clinicopathological exercises. Case 12-2002. A 50-year-old man with eosinophilia and fluctuating hepatic lesions. N Engl J Med 346(16):1232-1239
Viroj Wiwanitkit

wviroj@yahoo.com

Hainan Medical University, Haikou, China

2 WiwanitkitHouse, Bangkhae, Bangkok 10160, Thailand

3 dr DY Patil University, Navi Mumbai, India

4 Faculty of Medicine, University of Nis, Niš, Serbia

5 Joseph Ayobabalola University, Ilara-Mokin, Nigeria

6 Surindra Rajabhat University, Surin, Thailand 